PEMANFAATAN

VECTOR SPACE MODEL

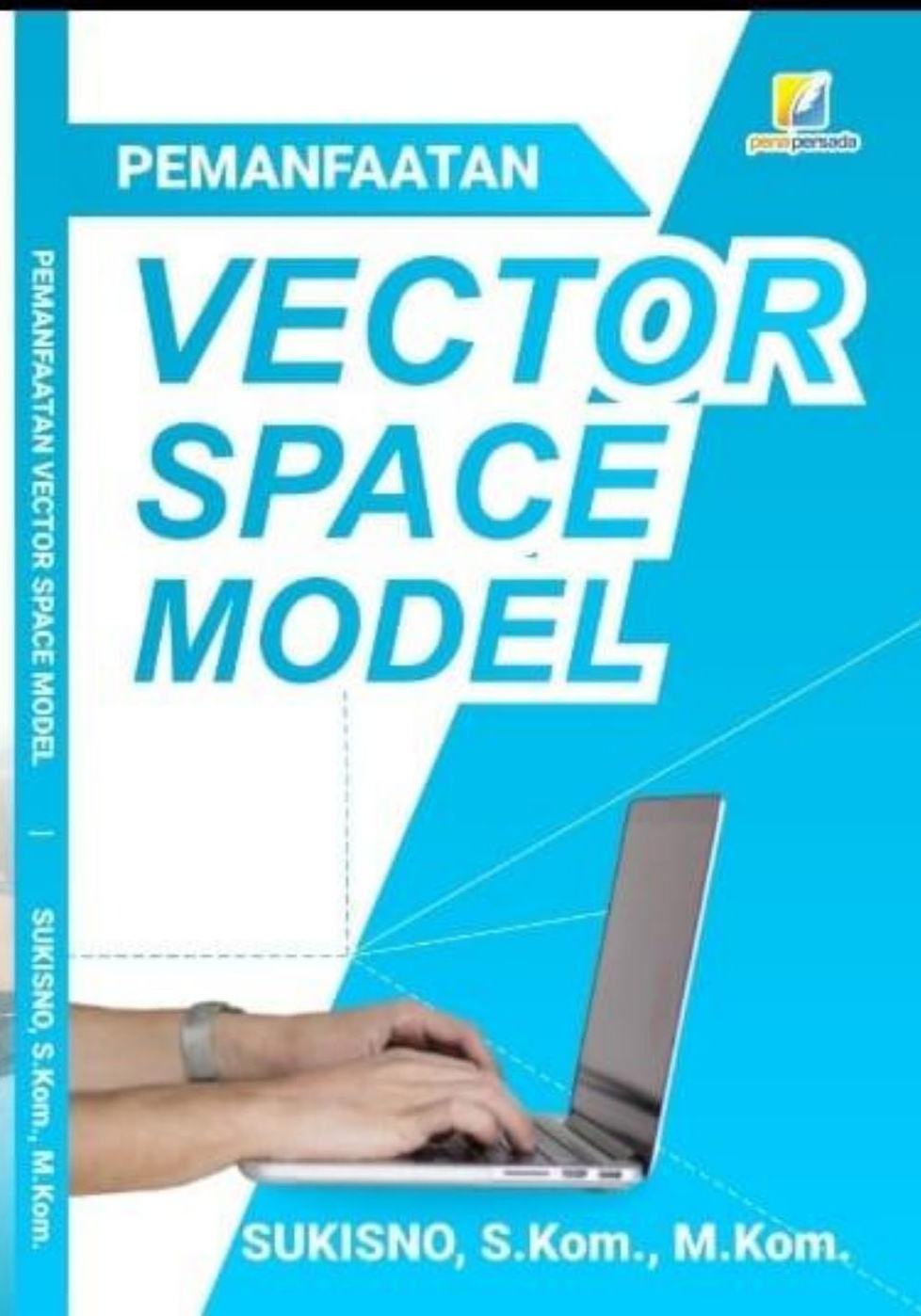




\section{PEMANFAATAN VECTOR SPACE MODEL}

Sukisno, S.Kom., M.Kom.

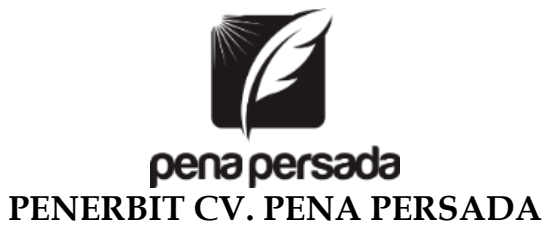


PEMANFAATAN VECTOR SPACE MODEL

Penulis:

Sukisno, S.Kom., M.Kom.

ISBN : 978-623-315-641-7

Editor:

Tri Hidayati

Design Cover :

Retnani Nur Briliant

Layout :

Hasnah Aulia

\section{Penerbit CV. Pena Persada}

Redaksi :

Jl. Gerilya No. 292 Purwokerto Selatan, Kab. Banyumas

Jawa Tengah

Email : penerbit.penapersada@gmail.com

Website : penapersada.com Phone : (0281) 7771388

\section{Anggota IKAPI}

All right reserved

Cetakan pertama : 2021

Hak Cipta dilindungi oleh undang-undang. Dilarang memperbanyak karya tulis ini dalam bentuk apapun tanpa izin penerbit 


\section{KATA PENGANTAR}

Puji syukur saya panjatkan kepada Tuhan Yang Maha Esa, karena atas berkat dan rahmat-Nya, saya dapat menyelesaikan buku ini. Penulisan buku merupakan buah karya dari pemikiran penulis yang diberi judul "Pemanfaatan Vector Space Model". Saya menyadari bahwa tanpa bantuan dan bimbingan dari berbagai pihak sangatlah sulit bagi saya untuk menyelesaikan karya ini. Oleh karena itu, saya mengucapkan banyak terima kasih pada semua pihak yang telah membantu penyusunan buku ini. Sehingga buku ini bisa hadir di hadapan pembaca.

Kajian dalam buku ini bertujuan untuk membantu pengguna dalam melakukan kategorisasi dokumen yang dibutuhkan secara cepat dan akurat. Dengan adanya aplikasi untuk proses kategorisasi dokumen yang menerapkan algoritma stemming Nazief Adriani dan Algoritma K-Nearest Neighbor, maka diharapkan dapat memudahkan dalam mengkategorisasikan dokumen serta mempermudah pengguna dalam mencari dokumen berdasarkan tingkat kemiripan (similarity) antara dokumen uji dan learning document.

Penulis menyadari bahwa buku ini masih jauh dari kesempurnaan. Oleh karena itu kritik dan saran yang membangun sangat dibutuhkan guna penyempurnaan buku ini. Akhir kata saya berharap Tuhan Yang Maha Esa berkenan membalas segala kebaikan semua pihak yang telah membantu. Semoga buku ini akan membawa manfaat bagi pengembangan ilmu teknologi informasi. 


\section{DAFTAR ISI}

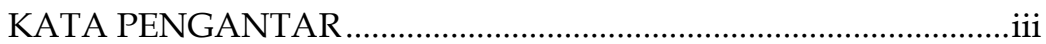

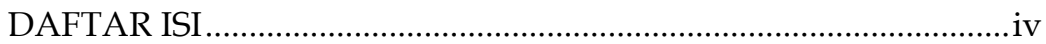

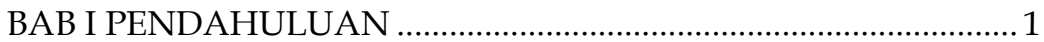

A. Kesalahan Penyimpanan Dokumen ........................................... 1

B. Pengkategorian Dokumen ..........................................................

C. Pembatasan Masalah............................................................... 4

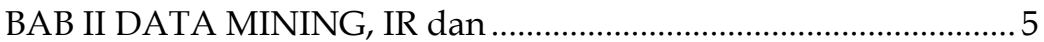

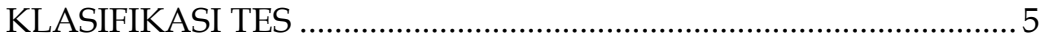

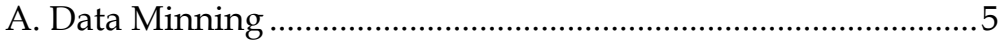

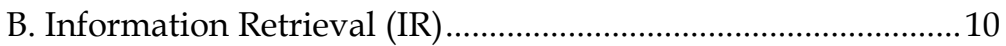

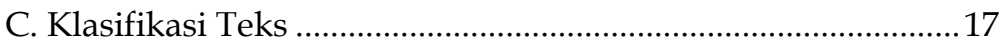

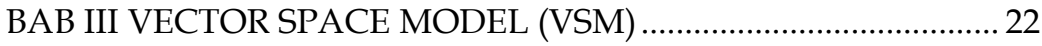

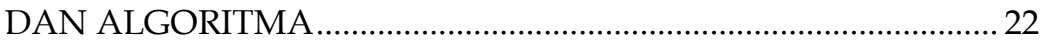

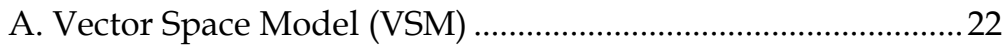

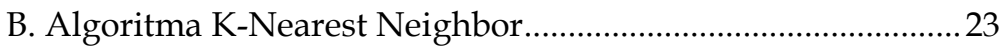

C. Stemming dan Algoritma Nazief Adriani ...................................24

D. Pembobotan Kata (Term Weighting) ............................................ 34

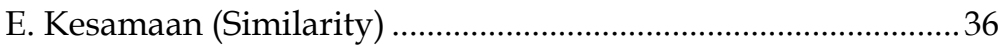

BAB IV MODEL REPRESENTASI DOKUMEN ……………............39

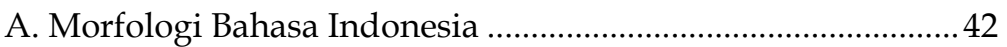

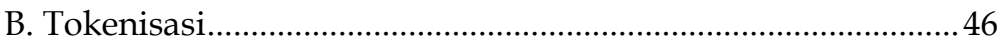

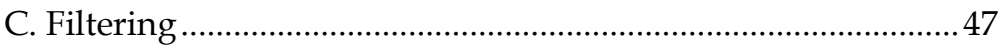

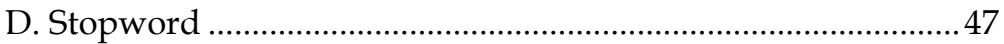

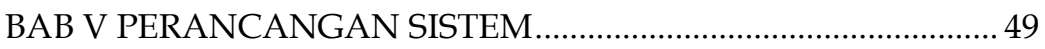

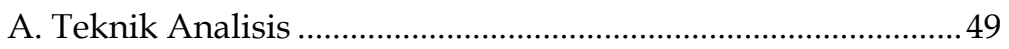

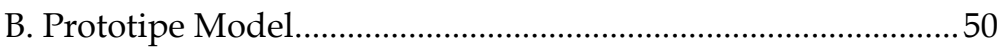

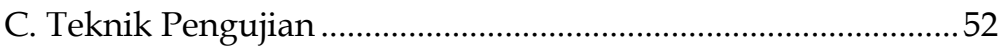

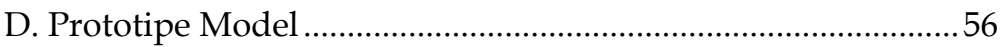

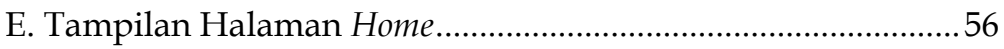

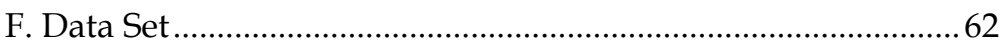

G. Learning Document dengan TF.IDF (Term Frequency Inverse Doc ument Frequency) dan WIDF (Weighted Inversed Document Frequency) 


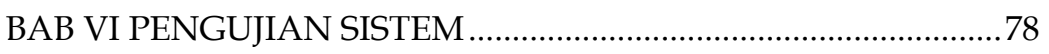

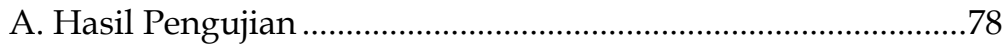

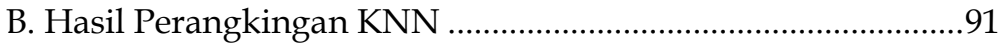

BAB VII IMPLIKASI DAN IMPLEMENTASI SISTEM ...................113

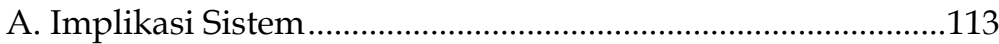

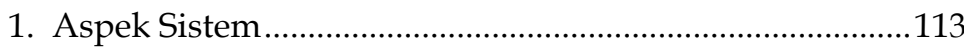

2. Aspek Manajerial.................................................................115

3. Aspek Kajian Lanjut...........................................................117

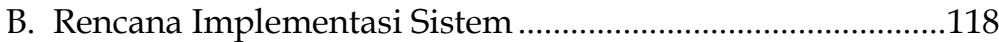

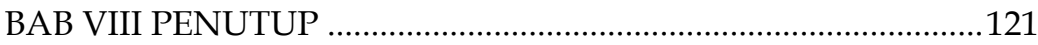

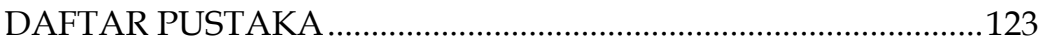




\section{PEMANFAATAN VECTOR SPACE MODEL}




\section{BAB I \\ PENDAHULUAN}

\section{A. Kesalahan Penyimpanan Dokumen}

Adanya pertumbuhan yang pesat dari informasi pada masa kini, menjadikan katagorisasi teks (text categorization) yang merupakan suatu proses pengklasifikasian dokumen ke dalam satu atau lebih kategori yang telah didefinisikan sebelumnya atau ke dalam kelas-kelas dari dokumen dokumen yang sama, sebagai suatu teknik kunci dalam penanganan dan pengorganisasian data yang berupa teks.

Kategorisasi teks merupakan salah satu tahap pemrosesan dokumen pada information retrieval, dimana dokumen-dokumen yang ada dikelompokkan atau diklasifikasikan kedalam beberapa topik atau tema.[Attardi 2004]

Pada kategorisasi teks, representasi suatu dokumen adalah kata, dimana tiap kata memiliki ciri khas yang berbeda. Oleh karena itu, pada sebagian besar proses kategorisasi teks, terdapat banyak ciri khas yang mungkin terjadi, baik ciri khas yang relevan dengan tema dokumen maupun yang tidak relevan dari proses kategorisasi. Adapun metode yang mengelompokkan semua ciri khas tersebut cenderung lebih baik daripada metode yang hanya mengelompokkan ciri khas yang relevan.[Mooney 2001]

Pada era globalisasi seperti saat ini dunia teknologi dan informasi perkembangannya sangat cepat, sehingga mendorong timbulnya kebutuhan manusia akan sebuah layanan informasi. Kemajuan teknologi yang sangat cepat mendorong manusia dalam memanfaatkan tumbuh kembangnya teknologi tersebut untuk melakukan pekerjaan yang dahulu dikerjakan secara manual. Terlebih lagi didorong dengan perkembangan ilmu pengetahuan yang sangat cepat. Sebagai contoh, dengan adanya teknologi komputer segala kegiatan dapat dilakukan dengan cepat dan meminimalkan 
resiko kesalahan. Perkembangan dokumen berbasis teks menyebabkan jumlah dokumen menjadi sangat besar dan menyebabkan pencarian dan klasifikasi didalam dokumen berbasis teks menjadi sebuah pekerjaan yang tidak mudah. Perkembangan tersebut direspon dengan penelitian di bidang informatika khususnya di bidang pemprosesan dokumen teks berbahasa Indonesia.

Tingginya penggunaan internet juga telah memacu pesatnya pertumbuhan dan pertukaran informasi. Tidak hanya dalam dunia maya, tetapi jumlah informasi dalam bentuk teks juga semakin banyak digunakan diberbagai institusi dan sekolah. Semakin banyak dokumen yang ada maka semakin banyak juga data yang tidak mudah untuk ditelusuri dan dikelompokan sesuai dengan kategori yang ada. Informasi yang dibutuhkan mengalami perkembangan mulai dari informasi yang bersifat umum maupun khusus. Banyaknya informasi dan dokumen yang tersedia mendorong manusia untuk mencari cara mendapatkan kumpulan informasi dan dukumen dengan waktu yang singkat dengan hasil yang valid. Apabila kumpulan informasi dan dokumennya sedikit, pencarian dapat dilakukan secara manual. Tetapi, apabila jumlah dokumen yang tersedia sangat besar,maka akan menghabiskan waktu dan tenaga. Dengan adanya komputer, menyimpan kumpulan informasi dan dokumen dalam jumlah yang besar dan menemukan informasi yang berguna dari kumpulan tersebut menjadi mungkin dan mudah.

Kesalahan pada kategorisasi secara manual masih bisa terjadi sehingga dapat kemungkinan terjadi kesalahan informasi. Melihat keadaan tersebut, membuat suatu fungsi kategorisasi data secara otomatis yang akan mempermudah dalam hal penentuan data yang diinginkan. Kategorisasi dokumen merupakan sebuah cara yang dapat digunakan untuk mempermudah pencarian dokumen dalam database. Kategorisasi merupakan salah satu metode dalam data mining yang bisa digunakan untuk mengelompokkan data. Kategorisasi merupakan proses pengelompokan dokumen 
sehingga semua anggota dari bagian data memiliki kemiripan berdasarkan perhitungan jarak antara kata dalam judul dokumen.

Jika jumlah dokumen semakin bertambah banyak maka proses pencarian dan penyajian dokumen menjadi lebih sukar atau sulit, sehingga akan lebih mudah jika dokumen tersebut sudah tersedia sesuai dengan kategorinya masing-masing. Sebagai konsekuensi, sangatlah penting untuk bisa mengorganisir dan mengklasifikasi dokumen secara otomatis. Klasifikasi dokumen teks adalah permasalahan yang sangat mendasar dan penting. Didalam dokumen teks, tulisan yang terkandung adalah bahasa alami manusia, yang merupakan bahasa dengan struktur yang kompleks dan jumlah kata yang sangat banyak. Oleh karena itu, permasalahan ini merupakan masalah yang cukup kompleks dikarenakan penggunaan bahasa alami tersebut.

Semakin meningkatnya kemajuan sistem komputerisasi, maka banyak sekali penyimpanan file atau dokumen oleh institusi baik sekolah maupun universitas. Sebuah dokumen dapat dengan mudah dikategorisasikan secara manual oleh manusia, tetapi jika dilakukan secara terkomputerisasi akan membawa permasalahan tersendiri. Begitu pula dengan mencari tingkat kemiripan atau similaritas suatu dokumen dengan dokumen lainnya, manusia dapat dengan mudah menentukan apakah suatu dokumen memiliki tingkat kemiripan atau similaritas dengan dokumen lainnya atau tidak, untuk itu pada penelitian ini akan dibuat sebuah tools yang dapat mengkategorikan dokumen dan mencari tingkat nilai similaritas antar dokumen secara terkomputerisasi.

\section{B. Pengkategorian Dokumen}

Dalam kajian ini teknik yang digunakan untuk memecahkan masalah diatas adalah dengan menggunakan teknik text mining untuk pengkategorian dokumen penulisan ilmiah. Sedangkan untuk mencari nilai similaritas suatu dokumen dengan dokumen lainnya menggunakan learning 
document yang didapat dari hasil pengkategorian dokumen dan algoritma yang digunakan adalah algoritma TF-IDF (Term Frequency - Inversed Document Frequency), WIDF (Weighted Inverse Document Frequency) dan algoritma Vector Space Model. Selain itu salah satu metode kategorisasi teks yang lainnya adalah algoritma K-Nearest Neighbour (KNN).

Dengan kajian ini diharapkan proses pengkategorian dokumen teks berbahasa Indonesia secara terkomputerisasi, hasilnya dapat sesuai dengan pengkategorian secara manual. Dan pengukuran tingkat similaritas dokumen dapat menunjukkan seberapa besar nilai similaritas dokumen dengan dokumen lainnya.

Berdasarkan hal tersebut, penulis akan mengkaji pengkategorisasian dokumen teks berformat Portable Document Format (PDF). Tujuan dari kajian ini adalah untuk implementasi sistem klasifikasi dokumen teks berbahasa Indonesia dengan banyak kategori sehingga dapat mempermudah dalam pencarian dokumen teks berbahasa Indonesia dan mengetahui tingkat akurasi hasil klasifikasi dengan metode TF-IDF, WIDF dan Vector Space Model dalam mengklasifikasikan dokumen teks berbahasa Indonesia.

\section{Pembatasan Masalah}

Batasan masalah dalam penulisan penelitian ini adalah sebagai berikut:

1. Agar tidak menyimpang dari pokok permasalahan, batasan masalah untuk informasi yang digunakan adalah berupa dokumen-dokumen berbahasa Indonesia yang dikutip dari beberapa artikel yang dapat berfungsi sebagai obyek data.

2. Term weight yang digunakan untuk mengukur pentingnya sebuah term dalam sebuah dokumen yaitu TF-IDF (Term Frequency.Inverse Document Frequency) dan WIDF (Weighted Inverse Document Frequency). 


\section{BAB II \\ DATA MINING, IR dan \\ KLASIFIKASI TES}

\section{A. Data Mining}

Text mining disebut juga dengan text data mining adalah suatu proses ekstraksi pola berupa informasi dan pengetahuan yang berguna dari sejumlah besar sumber data teks, seperti dokumen word, $p d f$, dan kutipan teks. Text mining mencari polapola yang ada diteks dalam bahasa natural yang tidak terstuktur seperti buku, email, artikel, halaman web. Kegiatan yang biasa dilakukan oleh text mining adalah text categorization, text clustering, conception / entity extraction.[Ari 2015] Data Mining didefinisikan sebagai proses penemuan pola dalam data.[Witten 2011]

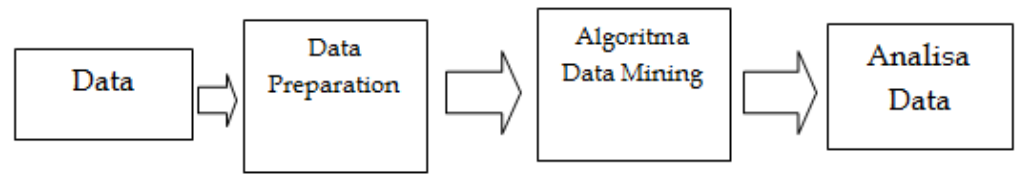

Gambar II-1. Langkah-langkah dalam Proses Data Mining."Maimon 2005]

Berdasarkan tugasnya, data mining dikelompokkan menjadi deskripsi, estimasi, prediksi, klasifikasi, clustering dan asosiasi. [Larose 2005] Proses dalam tahap data mining pada Gambar II-1 terdiri dari tiga langkah utama yaitu :[Sumathi 2006]

1. Data Preparation

Pada langkah ini, data dipilih, dibersihkan, dan dilakukan preprocessed mengikuti pedoman dan knowledge dari ahli domain yang menangkap dan mengintegrasikan data internal dan eksternal ke dalam tinjauan organisasi secara menyeluruh. 
2. Algoritma Data Mining

Penggunaan algoritma data mining dilakukan pada langkah ini untuk menggali data yang terintegrasi untuk memudahkan identifikasi informasi bernilai.

3. Fase Analisa Data

Keluaran dari data mining dievaluasi untuk melihat apakah knowledge domain ditemukan dalam bentuk rule yang telah diekstrak dari jaringan.

Text mining adalah salah satu bidang khusus dari data mining.[Feldman 2007] mendefinisikan text mining sebagai suatu proses menggali informasi dimana seorang user berinteraksi dengan sekumpulan dokumen menggunakan tools analisis yang merupakan komponen-komponen dalam data mining. Tujuan dari text mining adalah untuk mendapatkan informasi yang berguna dari sekumpulan dokumen.

Dalam memberikan solusi, text mining mengadopsi dan mengembangkan banyak teknik dari bidang lain, seperti Data Mining, Information Retrieval (IR), Statistic and Mathematic, Machine Learning, Linguistic, Natural Languange Processing (NLP) dan Visualization. Kegiatan riset untuk text mining antara lain ekstraksi dan penyimpanan teks, preprocessing akan konten teks, pengumpulan data statistik dan indexing dan analisa konten.[Triawati 2009] Tahapan dalam text mining meliputi tokenizing, filtering, stemming, tagging dan analyzing.[Mooney 2006]

Data Mining adalah suatu istilah yang digunakan untuk menguraikan penemuan pengetahuan di dalam database. Data mining adalah proses yang menggunakan teknik statistik, matematika, kecerdasan buatan dan machine learning untuk mengekstraksi dan mengidentifikasi informasi yang bermanfaat dan pengetahuan yang terakit dari berbagai database besar.[Turban 2005]

Menurut Gatner Group data mining adalah suatu proses menemukan hubungan yang berarti, pola dan kecenderungan dengan memeriksa dalam sekumpulan besar data yang tersimpan dalam penyimpanan, dengan menggunakan teknik 
pengenalan pola seperti teknik statistik dan matematika.[Larose 2005]

Selain definisi tesebut beberapa definisi juga diberikan seperti tertera dibawah ini:

1. Data mining adalah serangkaian proses untuk menggali nilai tambah dari suatu kumpulan data berupa pengetahuan yang selama ini tidak diketahui secara manual.[Pramudiono 2006]

2. Data mining adalah analisa otomatis dari data yang berjumlah besar atau kompleks dengan tujuan untuk menemukan pola atau kecenderungan yang penting yang biasanya tidak disadari keberadaannya.[Pramudiono 2006]

3. Data mining merupakan analisis dari peninjauan kumpulan data untuk menemukan hubungan yang tidak diduga dan meringkas data dengan cara yang berbeda dengan sebelumnya, yang dapat dipahami dan bermanfaat bagi pemilik data. [Larose 2005]

4. Data mining merupakan bidang dari beberapa bidang keilmuan yang menyatukan teknik dari pembelajaran mesin, pengenalan pola, statistik, database dan visualisasi untuk penanganan permasalahan pengambilan informasi dari database yang besar. [Larose 2005]

Kemajuan luar biasa yang terus berlanjut dalam bidang data mining didorong oleh beberapa faktor antara lain:[Larose 2005]

1. Pertumbuhan yang cepat dalam kumpulan data.

2. Penyimpanan data dalam data warehouse, sehingga seluruh perusahaan memiliki akses ke dalam database yang handal.

3. Adanya peningkatan akses data melalui navigasi web dan intranet.

4. Tekanan kompetisi bisnis untuk meningkatkan penguasaan pasar dalam globalisasi ekonomi.

5. Perkembangan teknologi perangkat lunak untuk data mining (ketersediaan teknologi).

6. Perkembangan yang hebat dalam kemampuan komputasi dan dan pengembangan kapasitas media penyimpanan. 
Dari definisi-definisi yang telah disampaikan, hal penting yang terkait dengan data mining adalah:[Kusrini 2009]

1. Data mining merupakan suatu proses otomatis terhadap data yang sudah ada.

2. Data yang akan diproses berupa data yang sangat besar.

3. Tujuan dari data mining adalah mendapatkan hubungan atau pola yang mungkin memberikan indikasi yang bermanfaat.

Hubungan yang dicari dalam data mining dapat berupa hubungan antara dua atau lebih dalam satu dimensi, misalnya dalam dimensi produk, kita dapat melihat keterkaitan pembelian suatu produk dengan produk yang lain. Selain itu hubungan juga dapat dilihat antara 2 atau lebih atribut dan 2 atau lebih obyek.[Ponniah 2001]

Sementara itu penemuan pola merupakan keluaran lain dari data mining. Misalkan sebuah perusahaan yang akan meningkatkan fasilitas kartu kredit dari pelanggan, maka perusahaan akan mencari pola dari pelanggan-pelanggan yang ada untuk mengetahui pelanggan yang potensial dan pelanggan yang tidak potensial. [Kusrini 2009]

Beberapa definisi awal dari data mining menyertakan fokus pada proses otomatisasi. Berry dan Linoff dalam buku Data Mining Technique for Marketing, Sales and Customers Support mendefinisikan data mining merupakan suatu proses eksplorasi dan analisis secara otomatis maupun semi otomatis terhadap data dalam jumlah besar dengan tujuan menemukan pola atau aturan yang berarti.[Larose 2005]

Tiga tahun kemudian dalam buku Mastering Data Mining, mereka memberikan definisi ulang terhadap pengertian data mining dan memberikan pernyataan bahwa jika ada yang kami sesalkan adalah frase "secara otomatis maupun semi otomatis" karena kami merasa hal tersebut memberikan focus berlebih pada teknik otomatis dan kurang pada eksplorasi dan analisis. Hal tersebut memberikan pemahaman yang salah bahwa data 
mining merupakan produk yang dapat dibeli dibandingkan keilmuan yang harus dikuasai.[Larose 2005]

Pernyataan tersebut menegaskan bahwa dalam data mining otomatisasi tidak menggantikan campur tangan manusia. Manusia harus ikut aktif dalam setiap fasa dalam proses data mining. Kehebatan kemampuan algoritma data mining yang terdapat dalam perangkat lunak analisis yang terdapat saat ini memungkinkan terjadinya kesalahan penggunaan yang berakibat fatal. Pengguna mungkin menerapkan analisis yang tidak tepat terhadap kumpulan data dengan menggunakan pendekatan yang berbeda. Oleh karenanya, dibutuhkan pemahaman tentang statistik dan struktur model matematika yang mendasari kerja perangkat lunak. [Larose 2005]

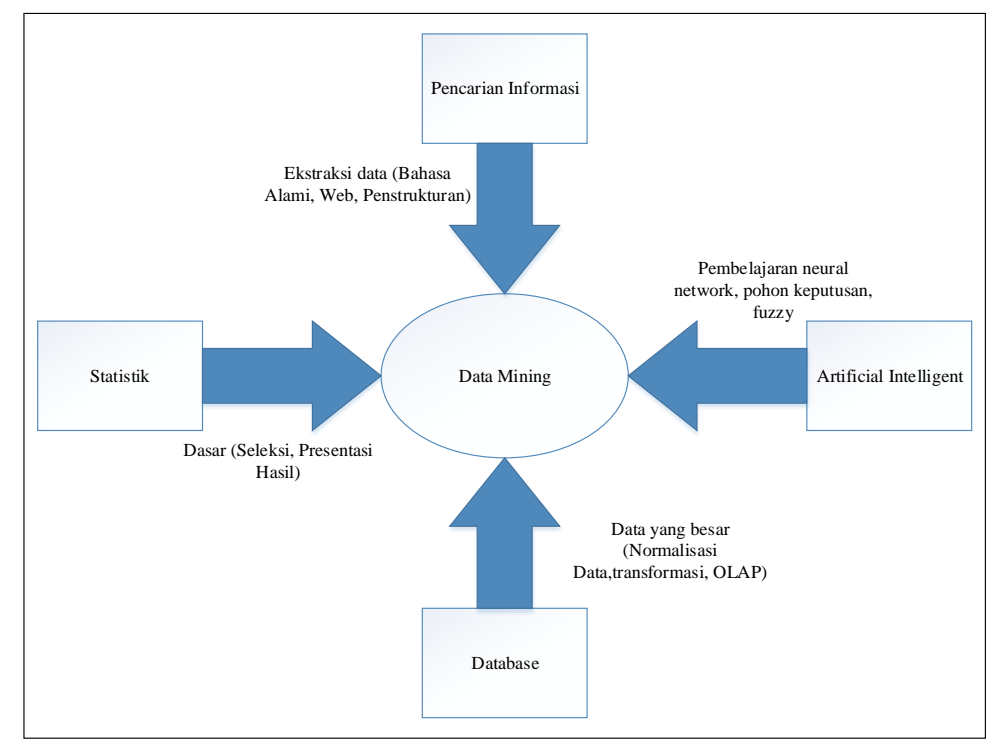

Gambar II-2. Bidang Ilmu Data Mining.[Pramudiono 2006]

Data mining bukanlah suatu bidang yang sama sekali baru. Salah satu kesulitan untuk mendefinisikan data mining adalah kenyataan bahwa data mining mewarisi banyak aspek 
dan teknik dari bidang-bidang ilmu yang sudah mapan terlebih dulu. Gambar II-2 menunjukkan bahwa data mining memiliki akar yang panjang dari bidang ilmu seperti kecerdasan buatan (artificial intelligent), machine learning, statistik, database dan juga information retrieval.[Pramudiono 2006]

\section{B. Information Retrieval (IR)}

Information retieval adalah ilmu untuk menemukan material yang umumnya merupakan dokumen-dokumen yang ditujukan untuk memenuhi kebutuhan informasi dari pemakai (user).[Christopher 2009]

Information retrieval (IR) system digunakan untuk menemukan kembali (retrieve) informasi-informasi yang relevan terhadap kebutuhan pengguna dari suatu kumpulan informasi secara otomatis.

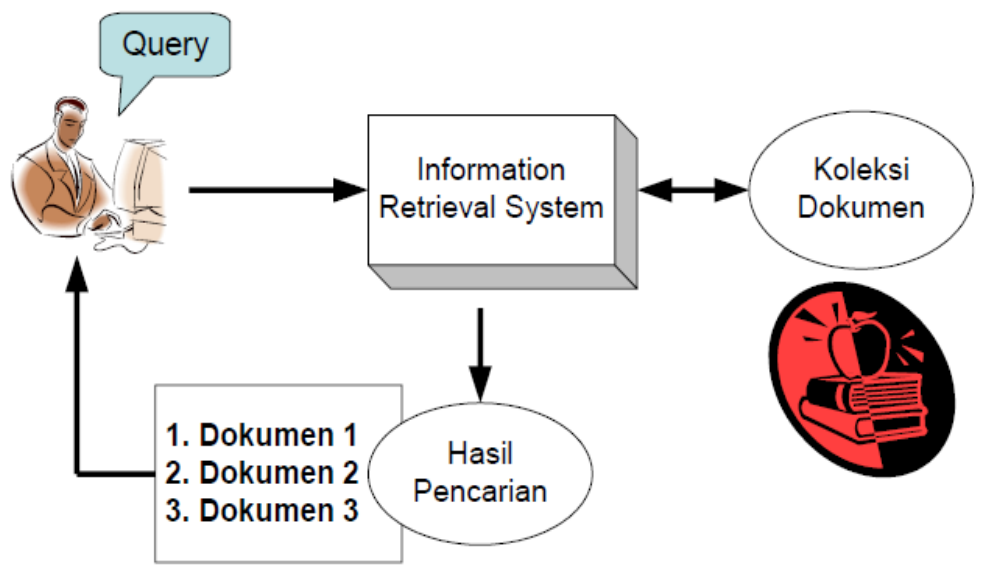

Gambar II-3. Ilustrasi information retrieval system. [Lasarus 2015]

Gambar II-3 menjelaskan tentang proses yang terjadi didalam Information Retrieval System terdiri dari 2 bagian utama, yaitu Indexing subsystem dan Searching subsystem (matching system). Proses indexing dilakukan untuk membentuk basis data terhadap koleksi dokumen yang dimasukkan atau dengan kata lain, indexing merupakan proses persiapan yang dilakukan terhadap dokumen sehingga dokumen siap untuk diproses. 
Proses indexing sendiri meliputi 2 proses, yaitu dokumen indexing dan term indexing. Dari term indexing akan dihasilkan koleksi kata yang akan digunakan untuk meningkatkan performance pencarian pada tahap selanjutnya.

Salah satu aplikasi umum dari IR system adalah search engine atau mesin pencarian yang terdapat pada jaringan internet. Pengguna dapat mencari halaman-halaman web yang dibutuhkannya melalui search engine. Contoh lain dari IR system adalah sistem informasi perpustakaan.

IR system terutama berhubungan dengan pencarian informasi yang isinya tidak memiliki struktur. Demikian pula ekspresi kebutuhan pengguna yang disebut query, juga tidak memiliki struktur. Hal ini yang membedakan IR system dengan sistem basis data. Dokumen adalah contoh informasi yang tidak terstruktur. Isi dari suatu dokumen sangat tergantung pada pembuat dokumen tersebut.

Sebagai suatu sistem, IR system memiliki beberapa bagian yang membangun sistem secara keseluruhan. Gambaran bagian-bagian yang terdapat pada suatu IR system digambarkan pada Gambar II-4. [Lasarus 2015]

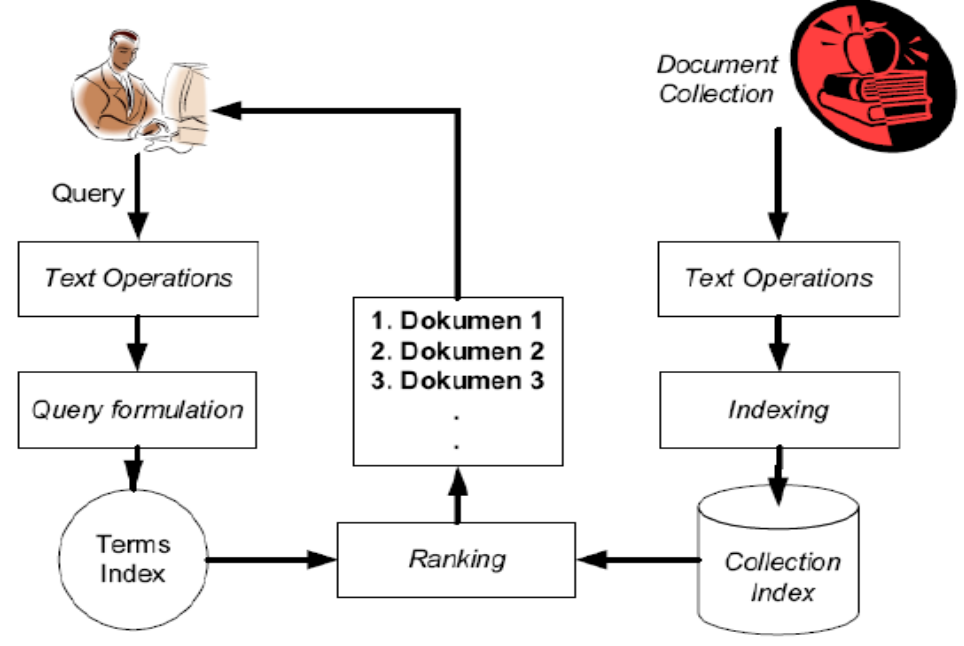

Gambar II-4. Skema Information Retrieval (IR) System [Lasarus 2015]. 
Gambar II-4 memperlihatkan bahwa terdapat dua buah alur operasi pada IR system. Alur pertama dimulai dari koleksi dokumen dan alur kedua dimulai dari query pengguna. Alur pertama yaitu pemrosesan terhadap koleksi dokumen menjadi basis data indeks tidak tergantung pada alur kedua. Sedangkan alur kedua tergantung dari keberadaan basis data indeks yang dihasilkan pada alur pertama.

Bagian-bagian dari IR system menurut gambar II-4 meliputi: [Lasarus 2015]

1. Text Operations (operasi terhadap teks) yang meliputi pemilihan kata-kata dalam query maupun dokumen (term selection) dalam pentransformasian dokumen atau query menjadi term index (indeks dari kata-kata).

2. Query formulation (formulasi terhadap query) yaitu memberi bobot pada indeks kata-kata query.

3. Ranking (perangkingan), mencari dokumen-dokumen yang relevan terhadap query dan mengurutkan dokumen tersebut berdasarkan kesesuaiannya dengan query.

4. Indexing (pengindeksan), membangun basis data indeks dari koleksi dokumen. Dilakukan terlebih dahulu sebelum pencarian dokumen dilakukan.

IR system menerima query dari pengguna, kemudian melakukan perangkingan terhadap dokumen pada koleksi berdasarkan kesesuaiannya dengan query. Hasil perangkingan yang diberikan kepada pengguna merupakan dokumen yang menurut sistem relevan dengan query. Namun relevansi dokumen terhadap suatu query merupakan penilaian pengguna yang subjektif dan dipengaruhi banyak faktor seperti topik, pewaktuan, sumber informasi maupun tujuan pengguna.

Model IR system menentukan detil IR system yaitu meliputi representasi dokumen maupun query, fungsi pencarian (retrieval function) dan notasi kesesuaian (relevance notation) dokumen terhadap query. 
Salah satu model IR system yang paling awal adalah model boolean. Model boolean merepresentasikan dokumen sebagai suatu himpunan kata-kunci (set of keywords). Sedangkan query direpresentasikan sebagai ekspresi boolean. Query dalam ekspresi boolean merupakan kumpulan kata kunci yang saling dihubungkan melalui operator boolean seperti $A N D$, OR, dan NOT serta menggunakan tanda kurung untuk menentukan scope operator. Hasil pencarian dokumen dari model boolean adalah himpunan dokumen yang relevan.

Kekurangan dari model boolean ini antara lain:

1. Hasil pencarian dokumen berupa himpunan, sehingga tidak dapat dikenali dokumen-dokumen yang paling relevan atau agak relevan (partial match).

2. Query dalam ekspresi boolean dapat menyulitkan pengguna yang tidak mengerti tentang ekspresi boolean.

Kekurangan dari model boolean diperbaiki oleh model ruang vektor yang mampu menghasilkan dokumen-dokumen terurut berdasarkan kesesuaian dengan query. Selain itu, pada model ruang vektor, query dapat berupa sekumpulan kata-kata dari pengguna dalam ekspresi bebas.[Lasarus 2015]

\section{Tujuan dan Fungsi Information Retrieval System}

Tujuan utama Information Retrieval System adalah untuk menemukan dokumen yang sesuai dengan kebutuhan informasi pengguna secara efektif dan efisien, sehingga dapat memberikan kepuasan baginya, dan sasaran akhir dari information retrieval system adalah kepuasan pemakai, defenisi menurut Taque-sutcliffe yang dikutip oleh [Lubis 2007].

Information Retrieval System didisain untuk menemukan dokumen atau informasi yang diperlukan oleh masyarakat pengguna. Information Retrieval System bertujuan untuk menjembatani kebutuhan informasi pengguna dengan sumber informasi yang tersedia dalam situasi sebagai berikut: 